\title{
Redesign of the platform for rollart's skate, centered on the needs of Mexican athletes
}

\section{Rediseño de la plataforma para el patín de rollart, centrado en las necesidades de los atletas mexicanos}

\author{
ZAMBRANO-CERVANTES, Ana Karen†, NIVÓN-PELLÓN, Alejandra* and GARCÍA-PITOL, Jorge \\ Arturo
}

Universidad Autónoma de Querétaro, Facultad de Ingeniería, México.

ID $1^{\text {st }}$ Author: Ana Karen, Zambrano-Cervantes / CVU CONACYT ID: 998095

ID $1^{\text {st }}$ Co-author: Alejandra, Nivón-Pellón / ORC ID: 0000-0002-1715-4335, Researcher ID Thomson: V-8717-2018, CVU CONACYT ID: 668097

ID $2^{\text {nd }}$ Co-author: Jorge Arturo, García-Pitol/ ORC ID: 0000-0001-5386-4329, CVU CONACYT ID: 432511

DOI: $10.35429 /$ JTP.2021.20.7.35.44

Received September 17, 2021; Accepted December 15, 2021

\begin{abstract}
Rollart is a discipline, based on an aspirational system that values aesthetics, ability and strength to perform the elements of competition, due to this, the design of specialized sports equipment must attend to the needs of resistance and design. The commercialization and production of specialized sports equipment is monopolized by foreign companies, focused on improving resistance, durability and the ease of exchange of parts, leaving aside the anthropometric measurements of their smaller markets, thus designing products with anthropometric measurements and needs different from those that Mexican athletes require. Skates are the main equipment of the Rollart, they are made up of boots, insoles and accessories. Therefore, the present research has the objective to redesign a skate platform, using a methodology centered on the needs of Mexican skaters, through design techniques and incremental innovation, which allows the development of local sports equipment. The research was validated by measuring the improvements in the performance of the execution of the elements of the discipline, as well as the appropriation and acceptance of the sports equipment by the skaters.
\end{abstract}

Artistic roller skate, Innovation, Product design

\begin{abstract}
Resumen
El patinaje artístico sobre ruedas es una disciplina con un sistema aspiracional, que valora tanto la estética como la habilidad y fortaleza para la ejecución de los elementos de competencia. Por esto, es necesario equipo deportivo especializado que considere un diseño exigente, resistente y estético. La comercialización en México de productos profesionales para esta área, se limita a marcas extranjeras enfocadas en la resistencia, durabilidad y facilidad de cambio de refacciones, y dejan a un lado las necesidades antropométricas de los atletas mexicamos. Debido a esto se considera pertinente que la antropometría de las atletas sea fundamental para el diseño de producto. Por lo cual, la presente investigación tiene como objetivo rediseñar una plataforma para patín, a través de una metodología centrada en las necesidades de patinadores mexicanos, mediante técnicas de diseño e innovación incremental, que permita el desarrollo de equipo deportivo local. La investigación se validó midiendo las mejoras en el rendimiento de los atletas durante la ejecución de elementos de la disciplina, así como, la apropiación y aceptación del equipo deportivo por parte de los patinadores.
\end{abstract}

Patinaje artístico sobre ruedas, innovación, diseño de producto

Citation: ZAMBRANO-CERVANTES, Ana Karen†, NIVÓN-PELLÓN, Alejandra and GARCÍA-PITOL, Jorge Arturo. Redesign of the platform for rollart's skate, centered on the needs of Mexican athletes Journal of Technological Prototypes. 2021. 7-20: 35-44

\footnotetext{
*Correspondence to Author (email: alejandra.nivón@uaq.mx)

$\dagger$ Researcher contributing first author
} 


\section{Introduction}

In Mexico, development, production and innovation of sports equipment is limited compared to other countries. Little attention to this sector has caused athletes to buy imported professional sports equipment. Such is the case of rollart, currently there are no Mexican brands dedicated to the production of professional equipment, which represents a disadvantage for Mexicans, who practice this discipline (Boen skates, s.f.; Roll line T.m. technology, s.f.; STD skates, s.f.; Toledo, 2017).

Skates are the main sports equipment of this discipline, and their elements that compose them are the boots, insoles and accessories. Insoles are the lower part of the skate, which are made up of two pieces, the platform and the trucks. The platform is the upper part of the insole where the boot is assembled and the trucks are placed on the bottom to install the suspensions and wheels, Figure 1 (Carmona \& Escobar, 2008; Komplex skate factory, s.f.; Roll line T.m. technology,

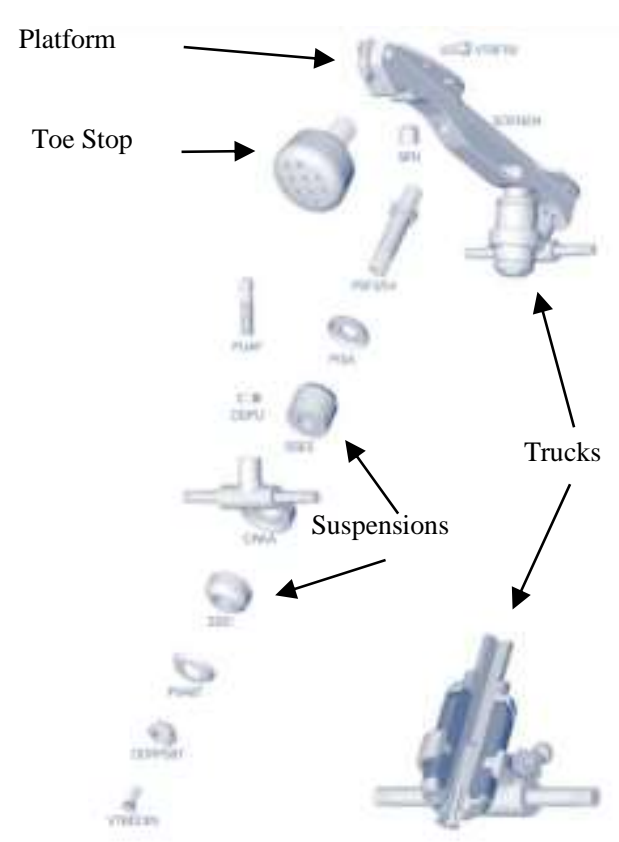

Figure 1 Insole Composition

Source: Modified from: Roll line T.m. technology. (s.f.) Patín libre. Obtained from Roll line T.m. technology: http://artisticskating.roll-line-it/es/productcategory/patin/patin-librel

Currently there are four foreign brands that produce professional insoles, which focus on resistance, durability and ease of replacement of spare parts (BOEN skates, s.f.; Komplex skate factory, s.f.; Roll line T.m. technology, s.f.; STD skates, s.f.).
Rollart has been gaining relevance recently, due to its inclusion in the international championships on the world sports scene, during the 2019 World Roller Games in Barcelona, Mexico managed to position itself in 18th place in the junior category and in 26th place in the senior category. (Carmona et al., 2008; World Skate Artistic Technical Commission, 2019).

Due to the recent relevance and importance of rollart, this research aims to redesign a skate platform, through a methodology focused on the needs of Mexican skaters, through design techniques and incremental innovation, which allows the development of local sports gear.

\section{Theoretical framework}

The specialized equipment for training rollart began to be designed in 1813 with the creation of wooden wheels by Jean Garcín. The first platform developed and patented was in 1912 by Runion, H. Subsequently, modifications were made to the lower part of the skate, known as Trucks, that increase flexibility and consequently, the athlete improves the ability to control movement when executing the elements of the discipline (Carmona et al., 2008; El rincón del patinador, 2007; Runion, 1912; Snyder, 1950; Sure-Grip Skate C.O., s.f.).

Over time, the development and improvement of the discipline has been based on the control of movement and the possibility of exchanging spare parts on the skates. It wasn't until 2012, when the stability was improved through sports equipment to facilitate the execution of the elements of the discipline (Mur, 2012). The platform of professional skates have had variations in the materials used, seeking greater resistance and lightness. It can be identified that the platform is an element to which modifications can be made to improve the stability in the athlete's jumps and at the same time, improve the lightness of the skate (Komplex skate factory, s.f.; Roll line T.m. technology, 2015).

Stability can be improved by decreasing the height of the center of gravity or increasing the base of support, which can be measured through the sensation of the user, when receiving the movement, this sensation is called proprioception (García y Rodríguez Marroyo, 2012; Sampietro, 2013).

ZAMBRANO-CERVANTES, Ana Karen†, NIVÓN-PELLÓN, Alejandra and GARCÍA-PITOL, Jorge Arturo. Redesign of the platform for rollart's skate, centered on the needs of Mexican athletes Journal of Technological Prototypes. 2021 
In skating, proprioception can be perceived during the execution of the jumps. In the rollart discipline there are six types of jumps, the Axel jump is one of them, which is mandatory to perform in competitions. It is essential that a rollart athlete knows how to perform the Axel jump regardless of their age or level. (Carmona et al., 2008; Comité técnico de la Federación internacional de Patinaje sobre ruedas, 2013; Garaú, 2017; International cup Uruguay, 2018; Martín, 2017; Patinaje artístico, 2017; World Skate Artistic Technical Commission, 2019).

The division of categories for international championships differs in national categories. In Mexico, the categories are divided by age and level of difficulty in the execution of the elements, as shown in Table 1. Only athletes belonging to the Junior and Senior categories can participate in international championships.

It is pertinent and essential to consider in the design of specialized sports equipment the anthropometry of the users, regardless of the level and age of the athletes.

\begin{tabular}{|c|c|c|c|c|}
\hline Level & Deslizables & Level B & Transition & Level A \\
\hline Category & \multicolumn{4}{|l|}{ Age } \\
\hline Micro & 5 to 6 years & $\begin{array}{l}5 \text { to } 6 \\
\text { years }\end{array}$ & - & - \\
\hline Premini & 7 to 8 year & $\begin{array}{l}7 \text { to } 8 \\
\text { year }\end{array}$ & - & - \\
\hline $\begin{array}{l}\text { Mini } \\
\text { infantil }\end{array}$ & 9 to10 years & $\begin{array}{l}9 \text { to } 10 \\
\text { years }\end{array}$ & 9 to10 years & $\begin{array}{l}9 \text { to10 } \\
\text { years }\end{array}$ \\
\hline Infant & 11 to 12 years & $\begin{array}{l}11 \text { to } 12 \\
\text { years }\end{array}$ & $\begin{array}{l}11 \text { to } 12 \\
\text { years }\end{array}$ & $\begin{array}{l}11 \text { to } 12 \\
\text { years }\end{array}$ \\
\hline $\begin{array}{l}\text { Basic } \\
\text { Juvenile }\end{array}$ & - & $\begin{array}{l}13 \text { to } 15 \\
\text { years }\end{array}$ & $\begin{array}{l}13 \text { to } 15 \\
\text { years }\end{array}$ & - \\
\hline Cadet & - & - & - & $\begin{array}{l}13 \text { to } 14 \\
\text { years }\end{array}$ \\
\hline Juvenile & - & - & - & $\begin{array}{l}15 \text { to } 16 \\
\text { years }\end{array}$ \\
\hline $2^{\circ}$ Fuerza & $\begin{array}{l}13 \text { years and } \\
\text { older }\end{array}$ & $\begin{array}{l}16 \\
\text { years } \\
\text { and } \\
\text { older }\end{array}$ & $\begin{array}{l}16 \text { years and } \\
\text { older }\end{array}$ & - \\
\hline $\begin{array}{l}\text { Junior } \\
\text { WRC }\end{array}$ & - & - & - & $\begin{array}{l}17 \text { to } 18 \\
\text { years }\end{array}$ \\
\hline $\begin{array}{l}\text { Senior } \\
\text { WRC }\end{array}$ & - & - & - & $\begin{array}{l}19 \\
\text { years } \\
\text { and } \\
\text { older }\end{array}$ \\
\hline
\end{tabular}

Table 1 Mexican National Categories Source: Own Authorship

\section{Methodological framework}

For the development of the applied methodology, two methodologies were analyzed that focus on meeting the needs and desires of the user, they are explained below: User Centered Design (UCD), which specializes in product design and seeks to involve the end user throughout the design process, from beginning to end, making the user the focus of all decisions, and Design Thinking (DT), focused on experiences which seeks not only to get closer to the user, but to empathize with him, understanding and solving his needs (Design Thinking, s.f.; No solo usabilidad, s.f.; Vaezipoura, et al., 2017).

According to the information collected, a combination of both methodologies was carried out to generate a proposal of product design in order to achieve the objective of redesigning a platform for skates, through a methodology focused on the needs of Mexican skaters.

The methodological proposal consists in three stages: the first stage focuses on empathizing with the user, to understand the population to whom the product is directed. In the second stage, the parameters of the new product are established based on the interests and needs of the population; the last stage, provides design tools that generate proposals for the new product, as shown in Figure 2 and in Table 2.

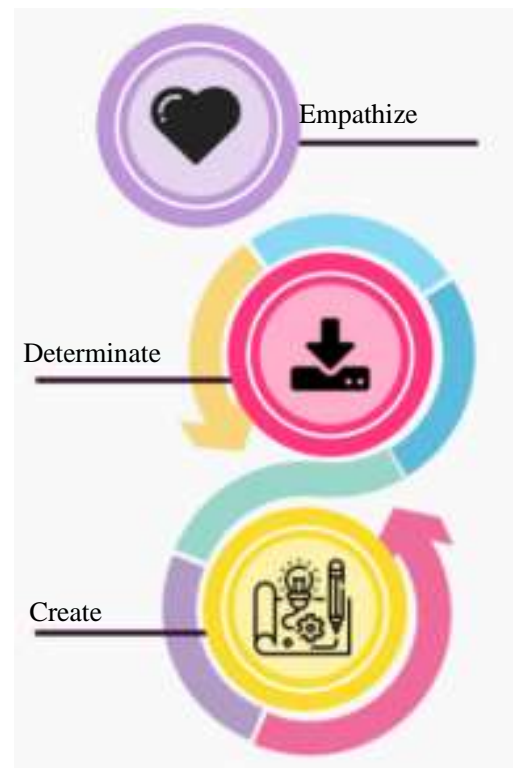

Figure 2 Stages of the Methodology Source: Own Authorship 


\begin{tabular}{|l|l|l|}
\hline \multicolumn{1}{|c}{ DCU } & \multicolumn{1}{c|}{$\begin{array}{c}\text { Design } \\
\text { Thinking }\end{array}$} & \multicolumn{1}{c|}{ Proposal used } \\
\hline & Stages & \\
\hline Explore & Empathize & Empathize \\
\hline Discover & Define & Determinate \\
\hline $\begin{array}{l}\text { Define and } \\
\text { design }\end{array}$ & Ideate & $\begin{array}{l}\text { Create: Conceptualize, } \\
\text { Prototype and Test. }\end{array}$ \\
\hline Test & Prototype & \\
\hline & Test & \\
\hline
\end{tabular}

Table 2 Stages of the Methodology

Source: Own Authorship

\section{Methodology}

\section{Empathize}

An approach was made with the community of rollart in the professional field, with athletes of different categories, including parents, coaches and judges in order to know and understand the user, their needs and their aspirations.

Authorization was obtained from the Mexican Federation of Roller Skates to have access to sport events of this discipline. The first approach was made during the National Course of Rollart for Judges and Coaches 2019, which was attended by fifty coaches and fifteen national judges.

During the 2019 Interasociations Championship, two hundred and fifty-four professional skaters was registered, of which two hundred and sixteen participants belonged to women's categories, in free style, due to this, only female athletes were considered to carry out an observational and anthropometric study.

Unstructured interviews were conducted with the parents of athletes in order to obtain information about their interests regarding sports products for athletes. For the observational study, photos and videos of athletes in competition and training were taken, images of accessories and clothing were also captured since the vanguard and design of these are a fundamental part of the skater's culture.

The present study was assisted by a nutritionist, who helped to carry out the anthropometric study. In order to study this discipline from the knowledge of the judges, coaches and athletes, they were asked to sign an informed consent, in which they were informed that the data collected would only be used for the present study.
The study was carried out with skaters from seven to twenty-four years old, of different categories and levels. The sample size was determined using Cochran's theorem, as shown below (Montgomery, 2008).

$n=\frac{216 \times 1.96^{2} \times 0.5 \times 0.5}{0.1^{2} \times(216-1)+1.96^{2} \times 0.5 \times 0.5}=66.67$

Due to the high interest of Mexican skaters, the study was carried out with eightyone participants from different states as Campeche, Mexico City, Chiapas, Coahuila, Jalisco, Morelos, San Luis Potosí, Puebla and Yucatán.

\section{Determinate}

Based on the data obtained in the previous stage, the design parameters were established considering the requirements to develop the product, as well as the desires, likes and needs of the user and thus generate a pleasant experience with the final product.

A reverse engineering study was carried out on the skates that are most requested and used by Mexican athletes. It was identified that the variety of boots and brands is wide and the measurements differ between the brands. Due to this, it was indicated that the proposed design should be adaptable to as many models as possible.

At the end of this stage, the characteristics of the studied population were established considering anthropometry, ages, sport categories and brands of skates used thus, the design requirements were determined to continue with the conceptualization and manufacturing process.

\section{Create}

To redesign the platform, digital sketches were made and a materials study was carried out in which it was initially identified that aluminum is the predominant material in this type of equipment. The first prototypes were made of aluminum; however, it was found that carbon fiber has better qualities of resistance and lightness, being this material suitable for the final prototype. 
Initially, the use of commercial trucks was considered, however, to preserve and even increase the stability of the new platform, the manufacture of new trucks with larger axle size was proposed.

Digital prototypes were made through modeling and rendering. Subsequently, 3D prints were generated to visualize the design and develop quick prototypes. Finally, resin samples with pigments and glitter were made to establish the possible colors and textures.

The samples were presented to female skaters between the ages of six and nine, as well as to parents in order to determine the colors and textures most accepted by users to incorporate them into the final product. The final prototypes were made with fiberglass molds and carbon fiber platforms, incorporating various colors, brightness and textures according to the samples presented.

Aesthetic and functional validation was carried out with the final prototypes, various textures and colors were presented to five parents, five beginner level athletes from six to nine years old and four intermediate level athletes aged from ten to sixteen belonging to the Morelense Association of Roller Skates. A measurement instrument was applied to identify the perception regarding the change in the weight of the skate, safety, professional appearance, aesthetics and acceptance.

These elements were measured on a commercial platform and the platform designed, in order to compare them. The prototypes were shown to a group of female athletes classified as Piece A and a commercial platform was shown, which was called Piece B. They were asked about the perception of each of the aforementioned characteristics and it was measured through five parameters.

To carry out the tests, a prototype was designed that consisted of placing the redesigned platform on a commercial platform, so that the athletes could carry out tests, practicing the elements of discipline. Finally, the perception of value regarding comfort, proprioception and satisfaction with functioning was measured through unstructured surveys, periodic reviews, and training videos.

\section{Results}

During the National Course of Rollart for Judges and Coaches 2019, it was mentioned that Mexican athletes had at that time a lower competitive level compared to other athletes from other countries registered in the World Roller championships, considering the ranking of the participating athletes and the difficulty of the elements performed in competition. Therefore, the Mexican Federation of Rollart increased and separated the categories by age and level, in order to allow the participants of a lower age and level to gain experience and gradually prepare for the categories of international size, see Table 2.

The observational study allowed to clarify the most common errors when performing the elements of the discipline such as: an incorrect posture when landing in the jumps, since some skaters do not maintain a steady posture. This error predominates in the execution of the Axel jump. With the unstructured interviews, it was identified that level A athletes have had training from two to four years to reach the level. Girls' sports career in the rollart discipline begins at the age of five and at this same age they begin to compete at basic levels.

The most valuable information in the study was that obtained from users, who are judges, athletes and coaches. The interviewed are interested in Mexican products focused on the discipline, especially if the products are designed by people who have experience in the discipline and knowledge of the needs of this sport. Parents expressed interest in Mexican products to reduce risks, costs and delivery times when purchasing imported products. The skaters showed interest in the customization of the sports equipment by incorporating colors, glitter, accessories and letters on the skates, as well as increasing their lightness to facilitate the execution of the elements of the discipline.

The anthropometric study revealed that the athletes within basic level categories have a lower muscular development compared to those who belong to advanced levels regardless of the age of the skaters. This is likely due the time invested to reach an advanced level in this sport. It is necessary to train more hours and a minimum of three years in the discipline. 
In addition, it was observed that those athletes who practice another discipline combined with rollart have an even greater development of muscle mass.

Due to the fact that the study was carried out with athletes from seven to twenty-four years old, there is great variation in the measurements. The weight range of the skaters is between 25.7 $\mathrm{Kg}$ and $62.1 \mathrm{Kg}$, key information to establish design parameters. It was identified that most of the athletes have a BMI (Body Mass Index) less than $25 \%$ (Graph 1), which indicates a low percentage of fat and an adequate weight for their height.

Two outstanding somatotypes are identified: the meso-endomorphic somatotype that prevails in athletes from the Yucatan, Mexico City and Campeche areas, while the meso-ectomorphic somatotype is characteristic of the participants from Jalisco, San Luis Potosí and Puebla.

\section{BMI}

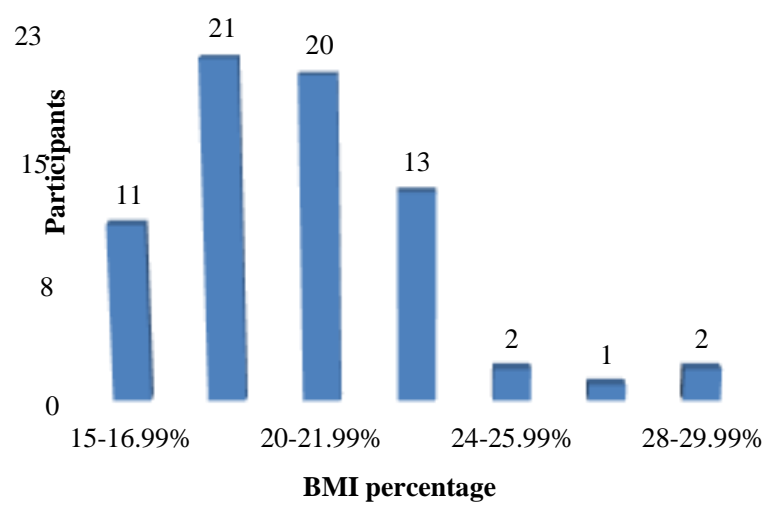

Graph 1 Body Mass Index in mexican skaters Source: Own authorship

The average shoe size is $23 \mathrm{~cm}$ (the smallest size is $19 \mathrm{~cm}$ and the largest $25.5 \mathrm{~cm}$ ). The sizes most frequently in Mexican skaters are 23 and $24 \mathrm{~cm}$, as shown in Graph 2.

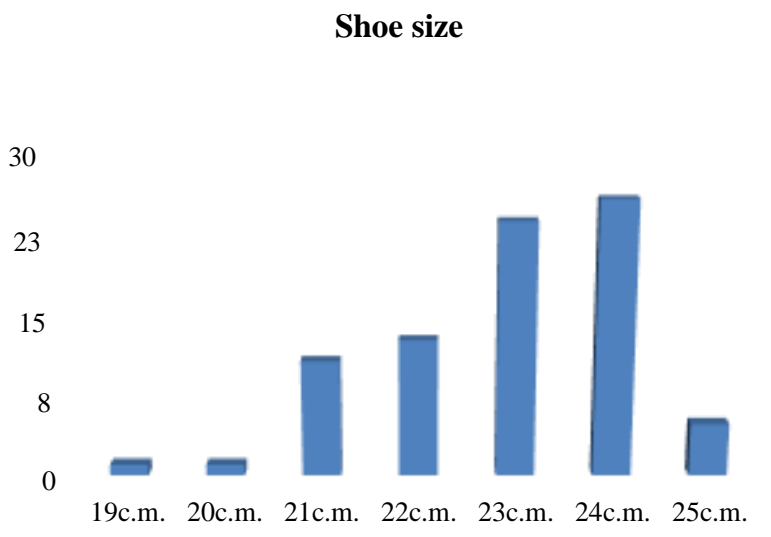

Graph 2 Shoe size

Source: Own Authorship

With this information, it became clear the importance of consider the needs of the studied population, from improving the skater's posture, increasing stability, contemplating anthropometric measurements, as well as the categories and interests in aesthetics considering the age variation.

The design requirements were determined based on the needs and aspirations of the users, as well as the requirements to develop the product considering the corresponding assemblies and the forces to which it will be subjected. The data are presented in Table 3 and divided into requirements and desires, the requirements are the most important, since they are the essential requirements to develop a functional platform.

\begin{tabular}{|l|l|l|}
\hline \multicolumn{1}{|c|}{ Requirements } & \multicolumn{1}{c|}{ Description } \\
\hline Stable & $\begin{array}{l}\text { With a gravity center that can } \\
\text { be measured through the height } \\
\text { and the base of the product. } \\
\text { Decreasing a centimeter in the } \\
\text { height and increasing a } \\
\text { centimeter in the base, } \\
\text { generates more stability in the } \\
\text { template, since the center of the } \\
\text { gravity lowers, and allows the } \\
\text { skater to perform the jumps } \\
\text { with more firmness in the fall. }\end{array}$ \\
\hline Light & $\begin{array}{l}\text { Incorporating materials such as } \\
\text { carbon fiber reduces weight. } \\
\text { According to athletes, reducing } \\
\text { weight helps to perform the } \\
\text { elements with les difficulty, } \\
\text { obtaining better results in } \\
\text { competition. In addition, it } \\
\text { generates more acceptance by } \\
\text { skaters. }\end{array}$ \\
\hline
\end{tabular}




\begin{tabular}{|l|l|l|}
\hline $\begin{array}{l}\text { Resistant to } \\
\text { weight of } 80 \mathrm{Kg} .\end{array}$ & $\mathrm{R}$ & $\begin{array}{l}\text { According the } \\
\text { anthropometric study carried } \\
\text { out in Mexican skaters, it was } \\
\text { identified that most of the } \\
\text { athletes have a BMI less than } \\
25 \% \text { and the highest weight in } \\
\text { skaters is 62.1 kg. Therefore, } \\
\text { considering a safety factor, the } \\
\text { maximum weight of the user } \\
\text { should be 80kg. }\end{array}$ \\
\hline $\begin{array}{l}\text { Interchangeable } \\
\text { accessories }\end{array}$ & $\mathrm{R}$ & $\begin{array}{l}\text { Interchangeable accessories } \\
\text { such as trucks, rubbers, toe } \\
\text { stops and wheels with } \\
\text { professional insoles, since they } \\
\text { are accessories that the skaters } \\
\text { change depending of their } \\
\text { needs. me }\end{array}$ \\
\hline Boot assembly & $\mathrm{R}$ & $\begin{array}{l}\text { Insole must be a modular } \\
\text { element with the boot that } \\
\text { allows the correct assembling } \\
\text { according to the skaters needs. }\end{array}$ \\
\hline Resistant to all \\
rollart elements. & $\mathrm{R}$ & $\begin{array}{l}\text { It must allow the correct } \\
\text { execution of all rollart } \\
\text { elements such as jumps and } \\
\text { pirouettes. } \\
\text { insoles mainly for their } \\
\text { performance and secondly for } \\
\text { the aesthetic. Shiny finishes } \\
\text { and color variations can be } \\
\text { included to make more } \\
\text { attractive design. }\end{array}$ \\
\hline
\end{tabular}

Table 3 Design Requirements Source: Own Authorship

The design was based on commercial insoles, preserving the length and width of the boots, as well as the perforations for the interchangeable accessories. Model simulations were carried out, considering the weight of the athletes with the safety factor, to determine its efforts and resistance. The resistance generated by using $60 \%$ carbon fiber generates a pressure of 3.308e+01 MPa, which does not represent any risk in the operation and use of the platform, Figure 3 (Rocha Rangel, et al., 2011).

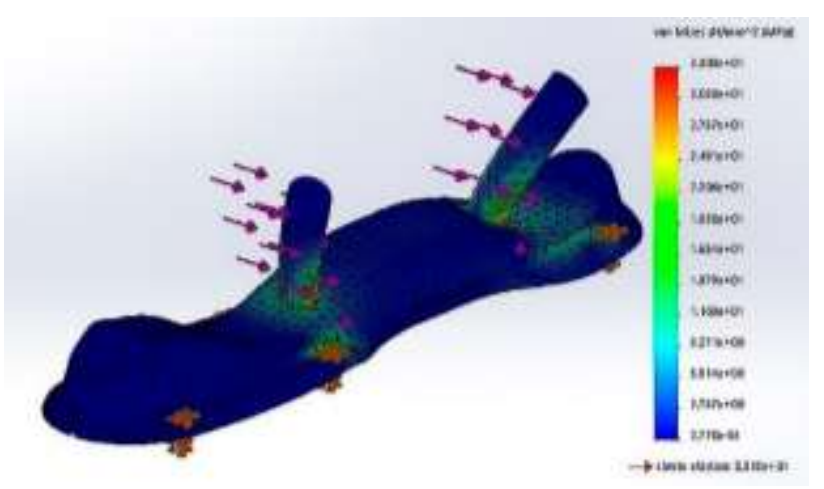

Figure 3 Resistance Simulation Source: Own Authorship
The functional prototype was built from a fiberglass mold, in which the carbon fiber was modeled, incorporating different colors and textures as shown in Figure 4. Destructive tests were carried out, once the physical tests and simulations in CAD programs were completed, aesthetic validation was performed with intermediate and beginner level athletes to compare the prototypes with commercial platforms.

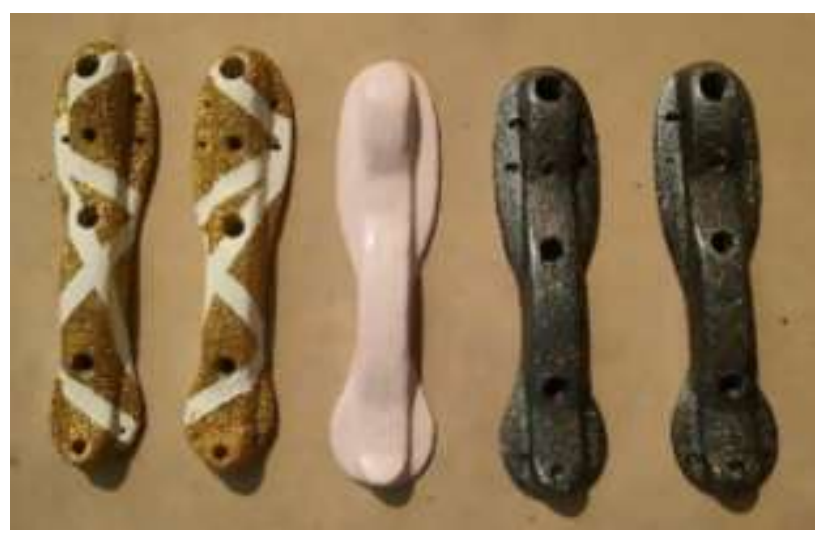

Figure 4 Final Prototypes with Color Variations Source: Own Authorship

$85 \%$ of the participants expressed a greater perception of safety with Piece A. All participants perceived that Piece $\mathrm{A}$ is lighter than Piece B. The commercial insole has a weight of 220 grams, while the final prototypes weighed 120 grams, which carries several advantages in athletes, including the sensation when using the product, reduction in muscular effort when performing the elements of the discipline and increase in the athlete's performance during training. Additionally, $85 \%$ of the participants considered Piece A more professional than Piece B.

The participating athletes considered that Piece A has better colors and textures; mentioning as his favorite the black one with iridescence glitter. They showed great interest in the option of personalizing the pieces with different colors, brightness and even names.

Finally, all the participants indicated that they perceived greater aesthetics in Piece A, therefore, they showed interest in acquiring the product to incorporate it into their gear. According to these results, the designed prototype presents an adequate acceptance among the majority of the participants, who are enthusiastic about the aesthetic changes, which diversify the existing products on the market. 
For the functional validation, the forces involved in the movements of the discipline were evaluated. The prototypes were assembled with the accessories to the boots and movements of the discipline were executed. The prototypes were used for a month by beginner and intermediate level athletes. At the end of the test time, the participants noticed improvement in the performance obtained, they managed to perform jumps of greater difficulty, as well as, perfect basic sliders.

The validation of the Axel jump was performed for each participant using the prototype (Piece A) and the commercial skating equipment (Piece B). The Axel jump, is the only one with a front entry, allows to identify the improvement in stability during the entry and fall of the same, it consists of making 1.5 revolutions in the air and landing with one foot, for which the execution of 10 jumps consecutively, for functional validation.

The average results are compared in Table 4 , considering the order of the executions of the Axel jump with the designed product and with the commercial one.

\begin{tabular}{|l|r|r|}
\hline \multicolumn{1}{|c}{ Attempt } & \multicolumn{1}{c}{$\begin{array}{c}\text { Average with } \\
\text { piece B }\end{array}$} & $\begin{array}{c}\text { Average with } \\
\text { piece A }\end{array}$ \\
\hline 1 & 3 & 5 \\
\hline 2 & 3 & 5 \\
\hline 3 & 0 & 4 \\
\hline 4 & 4 & 1 \\
\hline 5 & 3 & 4 \\
\hline 6 & 5 & 5 \\
\hline 7 & 0 & 5 \\
\hline 8 & 4 & 3 \\
\hline 9 & 4 & 0 \\
\hline 10 & 3 & 5 \\
\hline Overall rating & 2.9 & 3.7 \\
\hline
\end{tabular}

Table 4 Axel Jump Comparison Results Source: Own Authorship

Correct execution was evaluated according to discipline standards, where 0 means that the jump was not made and 5 indicates a correct execution. As seen in the result, the execution of the Axel jump improves when using the prototype, compared to the commercial equipment. Additionally, it was observed that the use of the prototype improves posture and provides greater stability when performing the jumps from the entrance to the execution of the same, according to the participants comments.

\section{Conclusions}

Working with high-performance athletes requires specialized methodologies for the design of performance-enhancing products. Rollart is an aspirational system, which values both aesthetics, skill and strength, which is why the design of equipment with specialized functions that considers the type of user according to their anthropometry is required, while also complying with aesthetic parameters that the discipline demands.

Carbon fiber for the manufacture of the platform presented several advantages such as increasing the resistance, durability, lightness and aesthetics of the platform, fulfilling the functionality and aspirations of the athletes, this generated greater acceptance by users, improving the experience from the perception of value, functionality and usability.

Rollart is a sport with various national variations in the categories, the level, the interests and the anthropometry, it requires a demanding, resistant and aesthetic design in the sports equipment that allows to fulfill the desires and needs generating acceptance on the part of the athletes and their parents.

Redesign the platform provided benefits and advantages for the athletes such as improving posture and the correct execution of the elements of the discipline. However, it also allowed to generate a sense of belonging with their sports team, due to the possibility of customizing the team according to their tastes, desires and aesthetic needs that the discipline requires, which increases the perception of value.

Designing and manufacturing local sports gear, that considers the needs of users, allows increasing research and innovation in areas of opportunity with little information, in addition to reducing risks and shipping time to acquire the product while also promoting the constant information update to improve the national market. 


\section{References}

Boen skates. (s.f.). Para profesionales por profesionales de la calidad desde 1946. Obtained from BOEN skates: http://www.boen.it/en/frames/106-mach-7$4 \times 110 . h t m l$

Carmona, J. F., \& Escobar, J. M. (2008). El proceso de formación de los saltos en categorías menores: elementos técnicos estructurales en la modalidad de patinaje artístico. (Monografia de licenciatura). Universidad Antioquia, Medellín.

Comité técnico de la Federación Internacional de Patinaje sobre ruedas. (2013). Reglamento especial y normas deportivas. (Reglamento). Comité Internacional de patinaje artistico.

Design Thinking. (s.f.). Design Thinking. Obtained from Design Thinking: http://www.designthinking.es/inicio/

El rincón del patinador. (2007). Historia del patinaje. Obtained from El rincón del patinador: https://web.archive.org/web/20140326024836/h ttp://patinajeartistico.es.tl/His

Garaú, E. (2017, January 17). Saltos en el patinaje artístico sobre ruedas. Obtained from Puro patín: https://puropatin.com/saltos-en-elpatinaje-artistico/

García López, J., \& Rodríguez Marroyo, J. A. (2012). Equilibrio y estabilidad del cuerpo humano. En Biomecánica Básica aplicada a la Actividad Física y al Deporte. Paidotribo, Barcelona.

International cup Uruguay. (2018). Reglamento Nivel Promocional 2018. Patinaje Artístico. (Reglamento). international cup uruguay , Uruguay. K.

Komplex skate factory. (s.f.). Komplex skate factory. Obtained from Komplex: http://www.komplex.it/

Martín, B. (2017). Biomecánica y patologías más frecuentes en la extremidad inferior en patinadores. (Monografia de licenciatura). Universitat de Barcelona, Barcelona.

Montgomery, D. (2008). Diseño y Análisis de experimentos. Arizona: Limusa Wiley.
Mur, C. (2012, September 27). España Patente $n^{\circ}$ ES $1077748 U$.

No solo usabilidad. (s.f.). Diseño Centrado en el Usuario $(D C U)$. Obtained from No solo usabilidad:

http://www.nosolousabilidad.com/manual/3.ht $\mathrm{m}$

Patinaje artístico. (2017, February 7). Saltos y figuras del patinaje sobre ruedas. Obtained from Patinaje artístico el mundo del patinaje: https://patinaje2017.wordpress.com/2017/02/07 /saltos-y-figuras-de-el-patinaje-sobre-ruedas/

Rocha Rangel, E., Rodríguez García, J. A., Martínez Peña, E., Elizabeth, R. G., Leal Cruz, A., \& Munive, G. (2011). Estudio de la resistencia mecánica de materiales compuestos poliméricos reforzados con fibra de carbono. Avances en Ciencias e Ingeniería, 81-88.

Roll line T.m. technology. (s.f.). Patín libre. Obtained from Roll line T.m. technology: https://artisticskating.roll-line.it/es/productcategory/patin/patin-libre/

Runion, H. (1912). United State Patente $n^{o}$ 43,063.

Sampietro, M. (2013, May 28). Propiocepción, Equilibrio, Estabilidad, Estabilidad estática y dinámica. ¿Todo es lo mismo? Obtained from GSE: https://g-se.com/propiocepcion-equilibrioestabilidad-estabilidad-estatica-y-dinamicatodo-es-lo-mismo-bp-N57cfb26d41282

Silvestre, S. (2018, August 8). Pequeñas empresas, grandes historias. Seguinte. Obtained from http://www.seguinte.inf.br/noticias/omelhor-de-gravatai/4998_Gravatai-anda-sobrerodinhas-pelo-mundo

Snyder, C. W. (1950). United States Patente $n^{o}$ 2,510,722.

STD skates. (s.f.). STD skates and wheels. Obtained from STD skates: http://stdskates.com/

Sure-Grip Skate C.O. (s.f.). Snyder plates. Obtained from Sure-Grip Skate C.O.: https://www.suregrip.com/category-s/136.htm 
Vaezipoura, A., Rakotonirainya, A., Hawortha, N., \& Delhommec, P. (2017, June). Enhancing eco-safe driving behaviour through the use of invehicle human-machine interface: A qualitative study. Obtained from Research Gate: https://www.researchgate.net/publication/31668 0273_Enhancing_eco-

safe_driving_behaviour_through_the_use_of_in -vehicle_human-

machine_interface_A_qualitative_study

World Skate Artistic Technical Commission. (2019). Rules For Artistic Skating Competitions. Obtained from World Skate: http://www.worldskate.org/artistic/about/regula tions/category/262-rule-books.html 